\title{
障害波遮断変成器のコイル配置に基づいた 各種構造と特性
}

\author{
正員矢 ケ崎 昭彦 (電研精機研究所)

\section{Various Structures Based on the Coil Arrangement of a Noise Cutout Transformer and Their Characteristics.} \\ Akihiko Yagasaki, Member (Denkenseiki Re. In. Corp.)
}

\begin{abstract}
With instruments,equipment,and systems becoming highly integrated and provided with intelligent functions,serious and wide-spread cases of noise interference are increasing.Isolating technologies, which enable smooth operation of entire systems by separating and isolating the electric circuit at key points and transmitting signals and power through different forms of energy,are thus becoming indispensable as countermeasures.

In a power circuit,the noise cutout transformer is the element that serves the role of isolation.

However,utilization of this element has been lagging due to there being several difficult problems in terms of magnetic coupling.Development and improvement of this element are thus urgently needed.

The function of a noise cutout transformer is to discriminate between the fundamental wave component in the coupling magnetic flux and the high frequency components corresponding to noise so that the mutual inductance between the primary and secondary coils is effected only by the former component. To achieve this purpose, it is considered essential for the coils to be separated from each other,instead of arranging them close together as in a conventional transformer,so that the high frequency magnetic flux, which is generated by the primary coil and passes through the air gap and insulation,will not interlink with the secondary coil.

In this paper,the structures that can be considered for application to an actual transformer and the effects that such structures can provide shall be determined and classified through theory and experiment.

The anticipated effects shall then be examined comparatively to contribute to future development and improvement.
\end{abstract}

キーワード：ノイズ防止，アイソレート，障害波遮断，弁別変成，コイルと相互誘導，減衰特性

\section{1.まえがき}

\section{（1）最近のノイズ障害の傾向}

高度情報化社会の発展に絶えずつきまとい，それを阻害 する要因に，情報技術装置類へのノイズ障害がある。対策 が追いつかず，すでに公害となるに至ったノイズ障害は依 然として増加する一方であり，深刻な事例も多くなってい る。ことに最近は意表を突く形態でにわかに現われたり， いちどきに広域にわたる被害を生む事例が増える傾向があ る。それは高度に多様な作業を営む電子装䈯類の出現と, それと情報技術装置との結合, 及びそれらの利用のネット ワーク化と時期を等しくしている。

(2) ノイズ障害の防止と回路のアイソレート

このようなノイズ公害の傾向とその防止対策において， ノイズを発生したり障害を受けたりする機器・装置類やシ
ステムについて見るとき，次のようなことが言える。

電気・電子機器類・情報技術装置類の実装密度が高く回 路が複雑になり，またシスデムが大規模になるに従い， イズに敏感なデバイスもノイズを発生するデバイスも共に 增加し，さらに輻射ノイズを伝搬するアンテナとなる線路 も複雑に增大する。その結果，伝導性ノイズによる妨害も 放射性ノイズによる妨害も共に増加し，各部分の動作によ る相互干涉も避けられなくなって行く。従ってこれらの回 路のすべてが電気的に接続され導通したままであると，遂 にはどうやってもノイズ障害が防止できないようにまでな り，全体が極めてぜい弱化してしまう。

そこでこれを，動作電流が導通して一巡する必要のある 動作ループごとの小さなユニットに分割し，互いに電気的 に絶縁してノイズの伝導を遮断し，また輻射による伝播を 抑制した後に，必要な信号や電力だけを別のエネルギ（結 
合エネルギ）に変換し更に逆変換して伝達することによっ て，全体として順調な動作を営ませる技術（アイソレート 技術) がどうしても必要になる ${ }^{1 !} 。$

アイソレート技術は間に合わせに何かを付加してしのぐ 類のノイズ対策ではなく，基本的な回路技術に含まれるべ きものである。

（3）アイソレート素子

回路をアイソレートする役割を担うのがアイソレート素 子であり，その結合エネルギには主として信号系に光が， 電力系に磁気が害用できる。少なからぬ年月筆者の研究開 発してきた障害波遮断変成器 (Noise Cutout Transformer) (NCTと略記) は後者である(2) (3)(4) (5)-(10)。

光を結合エネルギとするアイソレート（光結合）の明快 さに比べ，磁気結合には難題が多く，そのためもあって素 子の開発も活用もかなり遅れている。しかしノイズによる トラブルの現場では電源回路回りへの施策を抜きにして解 決することはほとんど無く，しかも前記（2）のようにアイ ソレートを必須とする状況が急增している。電力系用アイ ソレート素子のさらなる開発・改良・普及は今なお急務で ある。

（4）電力回路用アイソレート素子「障害波遮断変成器」

漏えい変圧器等のごく限られた用途以外のほとんどすべ ての変成器の特性は，1次側電気勢力の全成分を損失なく2 次側に伝達する「全変成」を指向している。これに対し， 障害波遮断変成器の特性は, 必要な基本波の成分のみを伝 達し他の不必要な成分を伝達させない「弁別変成」を指向 する点で相反している。

ノイズ防止の目的に合わせて弁別変成を行わせるために は，1次と2次間の基本波に拈计る相互誘導作用を効率良く 行なわせると同時に，ノイズに相当する基本波より高い周 波数の相互誘導作用を極力抑制させる必要がある。そのた めの手法として, 変成器の1次コイルと2次コイルを共通し て貫通する磁心に，実効透磁率が基本波付近の交流周波数 においてはできるだけ高く，それより周波数が増すに従い 急速に実効透磁率が低下する材質と形状に設計する必要が あるが，それによって助長される困難もあり，新たな課題 が生まれる。

\section{（5）障害波遮断変成器の課題}

それは1次コイルに加わる電気勢力によって発生した磁 束のうちの，低い周波数の成分は実効透磁率の高い磁心 に吸い寄せられて空中に拡がることが甚だ少ないのに対 し, 高い周波数の成分程実効透磁率の低くなった磁心か ら離れて，コイル内の空隙や絶縁物等の非磁性体(これ らを合わせて空心と同等のものが併存すると考え，以下空 心と記す）中とその周辺の空間に自由に搪がって通るよ うになり，その結果高周波のノイズ程良く2次側に誘導し 伝達してしまうことにある。言いかえれば，設けられた磁 心と共に構造上不可否的に存在する空心とその周辺の空 間が，高い周波数のノイズに扔いては支配的にさえなるの

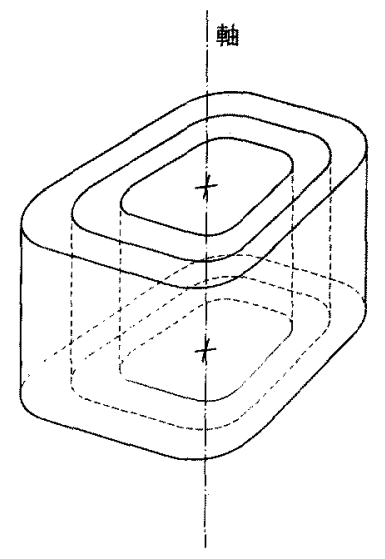

図 1 変成器一般のコイル配置

Fig. 1. Coil arrangement of conventional transformer

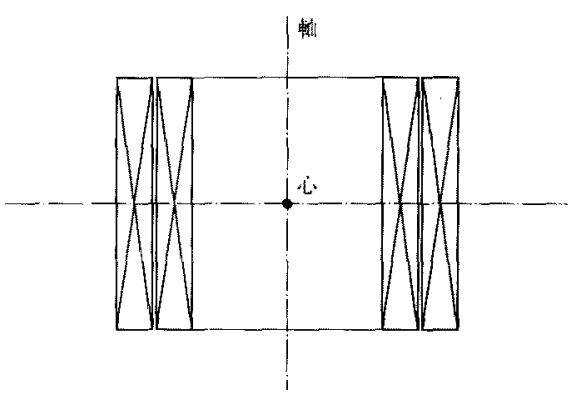

図2 同軸同心配置のコイルの縦断面

Fig. 2. Vertical cross sectional view of a coaxial concentric coil arrangement

であって, 一昔前と異なり $\mathrm{MHz}$ 带以上の周波数带域の， イズが甚しい障害を及ほすようになった現在では，これを いかにして解決するかがノイズ防止用変成器としての重要 な課題となる。

（6）課題に答える一手法（本稿のテーマ）

この課題を解決して行く手法として，先ず而コイルの位 置関係を，コイルから生じて空心とその周辺の空間を通る 高周波磁束が互いに相手コイルにできるだけ鎖交しないよ うに定めることが最も必要なことのひとつになる。

本稿ではそれはなぜかということと，沉用の变成器に実 施し得る形状を前提としたとき実現可能な位置関係に 3 種 類の基本形が存在することを示し，その中の最も高い効果 を示すツイスト形について最近の成果をあげる。そしてそ れに全变成指向の位置関係を加えた 4 種類について, 先ず 空中に両コイルのみを配置した場合（空心コイルのみとな る）について，次にコイルに磁心を加えて組合わせた場合 について，考察と実験を行い，各々の効果や用途について 比較論述する。 


\section{2. 一般の変成器の機能とそのノィズ防止効果上の 考察}

比較に先立って一般の変成器の持つ構造・機能とノイズ 防止上から見た効果に触れる。

一般の変成器に扔いては，コストの許す限りできるだけ 広い周波数带域にわたって透磁率の高い材質と形状の磁心 を設け，特に大型のものの一部を除きほとんど例外なく図 1，図2のように1次コイルと2次コイルを同軸同心状に配 置する。さらに雨コイルの高さ（軸長）をそろえ，冷却と 絶縁耐電圧上許される限り雨者を密接させる。また一個の 中間タップを取り出すにも可能な限り配慮して磁束の流れ を乱すまいとする。これらはすべて1次コイルで発生した 磁束を磁心のみならず空心と周辺の空間を通る磁束も残り なく2次コイルに鎖交させたいためにとる手法であり，「全 変成」の目的に向けて1次側電気勢力を少しの損失もなく 2次側に伝達したいための手段である。

しかしこのままではノイズの高周波磁束も良く 2 次コイ ルに鎖交するからノイズ防止の役には立ちにくい。また両 コイル間に静電遮へい板を設けても，磁束を遮ることはで きないので，基本波と同一経路で流れるノーマルモードノ イズの防止には役立たないい。

\section{3. 障害波遮断変成器の機能の概要と課題}

これに対し障害波遮断変成器の持つべき機能と構造は， 必要な成分である基本波を1次と 2 次の両コイル間で良く 伝達できると同時に，それより高い周波数の不要成分を伝 達させない「弁別変成」のためのものであるから，そのた めの構造も自ずから異なったものになる。どのような構造 を取るのが適当か考察する。

まず変成器の1次側に入力された電気勢力が 2 次側に伝 達される間に介在する要素には，図3のように抵抗 $R$ と電

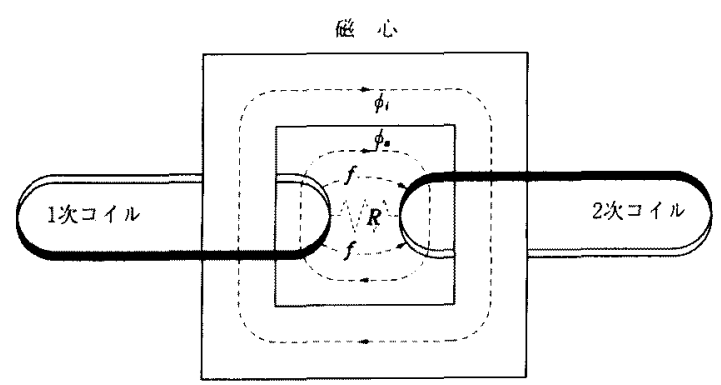

фi磁心中を通り両コイルに鎖交する磁束

ф。空心・空間・絶縁物を通り两コイルに鎖交する磁束

$f$ 再コイルを結ぶ電気力線

$R$ 两コイル間の釈縁抵抗

図 31 次・2次コイル間の結合説明図

Fig. 3. Explanation diagram of coupling between the primary and secondary coils
気力線 $f$ と磁束 $\phi_{i} \cdot \phi_{a}$ が想定される。その各々の作用と， テーマに対して望ましい処理の方向についてみる。

$R$ は絶緣抵抗であり，良質の絶縁物を用いて值を大きく すれば，これを介するノイズの伝導は基本波電流の漏洩と 合わせて容易に無視できるまでに除き得る。

fは電気力線であり，その静電誘導によるノイズの伝達 は，多重の良伝導板で隙間なく覆って遮へいすれば検知し 難いまでに防止できる。

次に磁束によるノイズの誘導のうち，磁心中を通る磁束 $\phi_{i}$ については，基本波付近の低周波では実效透磁率が高く高周 波になるに従って急速に低下する磁性材料を用いることによ って弁別し，ノイズによる成分を消失させることができる。 これに対し構造上不可避的に存在する空心と周辺の空間を通

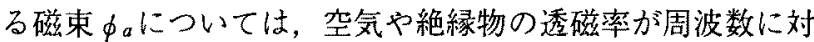
して一定であるためこれを弁別することができない。

つまり，障害波遮断変成器がその目的とするノイズ防止 の機能を持つためには，この磁束 $\phi_{a}$ をゔう処理するかが容 易ではなく，最後に残る課題しなる。

\section{4. 障害波遮断変成器のあるべきコイルの配置}

〈4・1〉両コイルを引離すここの課題を果たすためのひ とつの手法として，コイルの配置を一般の変成器とは反対 に互いに密接させずに引き離して配置することが考えられ る。そのことにより先ず空心とその周辺の空間を通る磁束 が2次コイルに鎖交することをできる限り避ける。それに よって空心と空間中の基本波の磁束も鎖交できにくくなる が，もともと基本波の磁束は奏效透磁率の高い磁心中を通 り，空心と空間中に漏れるのはごくわずかであるからこ の場合は多少の効率を犠牲にしても，これらを共にした総 ての者排除してしまう万が得策である。

以下それにより得られる効果を考察する。

〈4・2〉引き離したコイル間の相互誘道 最も単純な形 の図 4 に示した単層巻円筒形コイルを取上げて，これを一般 変成器と同様の同軸同心状に近接して空中に配置した場合 (A) と，これを軸方向に引き離して同軸異心状に隣接して配 置した場合 (B) との相互誘導の強さの相違を求めてみる ${ }^{122 !}$ 。

図4に拈いて、コイルの巻数 $\quad N_{1}=N_{2}=30$ 回 コイルの長さ $\quad l=0.03 \mathrm{~m}$ 内コイルの半径 $d_{1}=0.01 \mathrm{~m}$ 外コイルの半径 $d_{2}=0.015 \mathrm{~m}$ $x-\frac{l}{2}=0.005 \mathrm{~m}$ として

相互インダクタンス $M_{a} \cdot M_{b}(\mathrm{H})$ を求めると $(\mathrm{A})$ の配置では $M_{a}=\frac{2 \times 10^{-7} \pi^{2} R_{1}^{2} N_{1} N_{2}}{d}\left[1+\frac{R_{1}^{2} R_{2}^{2}}{8 d^{4}}\left\{3-4 \frac{\left(\frac{l}{2}\right)^{2}}{R_{1}^{2}}\right\}\right] \cdots(1)$

但 $L d=\sqrt{R_{2}{ }^{2}+\left(\frac{l}{2}\right)^{2}}$

$M_{a}=7.68[\mu \mathrm{H}]$ 


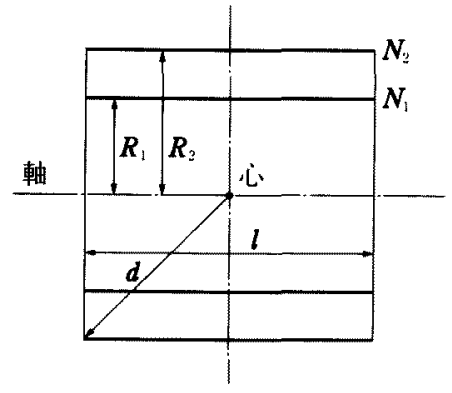

(A) 同軸同心配置

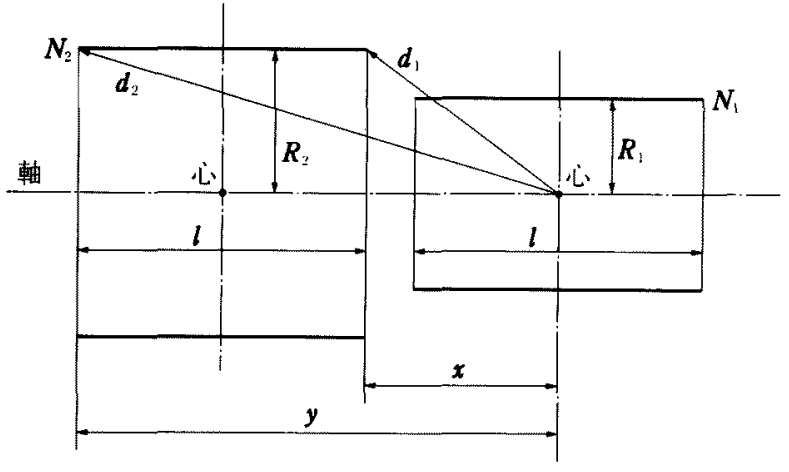

(B) 同軸異心配置

図 4 単層巻円筒コイル

Fig. 4. Single layer cylindrical coil

(B) の配置では

$$
M_{b}=\frac{10^{-7}\left(\pi R_{1} R_{2}\right)^{2} N_{1} N_{2}}{l^{2}}\left(k_{1} q_{1}+k_{3} q_{3}\right)
$$

但 $d_{1}=\sqrt{x^{2}+R_{2}^{2}}, d_{2}=\sqrt{y^{2}+R_{2}^{2}}$

$$
\begin{aligned}
& k_{1}=\frac{2}{R_{2}^{2}}\left(\frac{y}{d_{2}}-\frac{x}{d_{1}}\right), q_{1}=l, k_{3}=\frac{1}{2}\left(\frac{x}{d_{1}^{5}}-\frac{y}{d_{2}^{5}}\right), \\
& q_{3}=R_{1}^{2} \frac{l}{2}\left\{3-4 \frac{\left(\frac{l}{2}\right)^{2}}{R_{1}^{2}}\right\}
\end{aligned}
$$$$
M_{b}=0.74[\mu \mathrm{H}]
$$

(1) 式と (2) 式の答 $M_{a}$ と $M_{b}$ の比が1次・2次間のノイズ減 衰率 $A$ に相当すると見ると

$$
\begin{aligned}
A & =20 \log _{10} \frac{M_{b}}{M_{a}}[\mathrm{~dB}] \\
& =20 \log _{10} \frac{0.74}{7.68}=-20.32[\mathrm{~dB}]
\end{aligned}
$$

考察すると両コイルを図4（A）の同軸同心状の配置から 同軸異心の図 4 (B) の配置に引き離しただけで約ー $20 \mathrm{~dB}$ のノイズ減率率を稼ぐ可能性のあることがわかる。

$\langle 4 \cdot 3\rangle$ コイルの配置の分類と相互誘道の比較 沉用

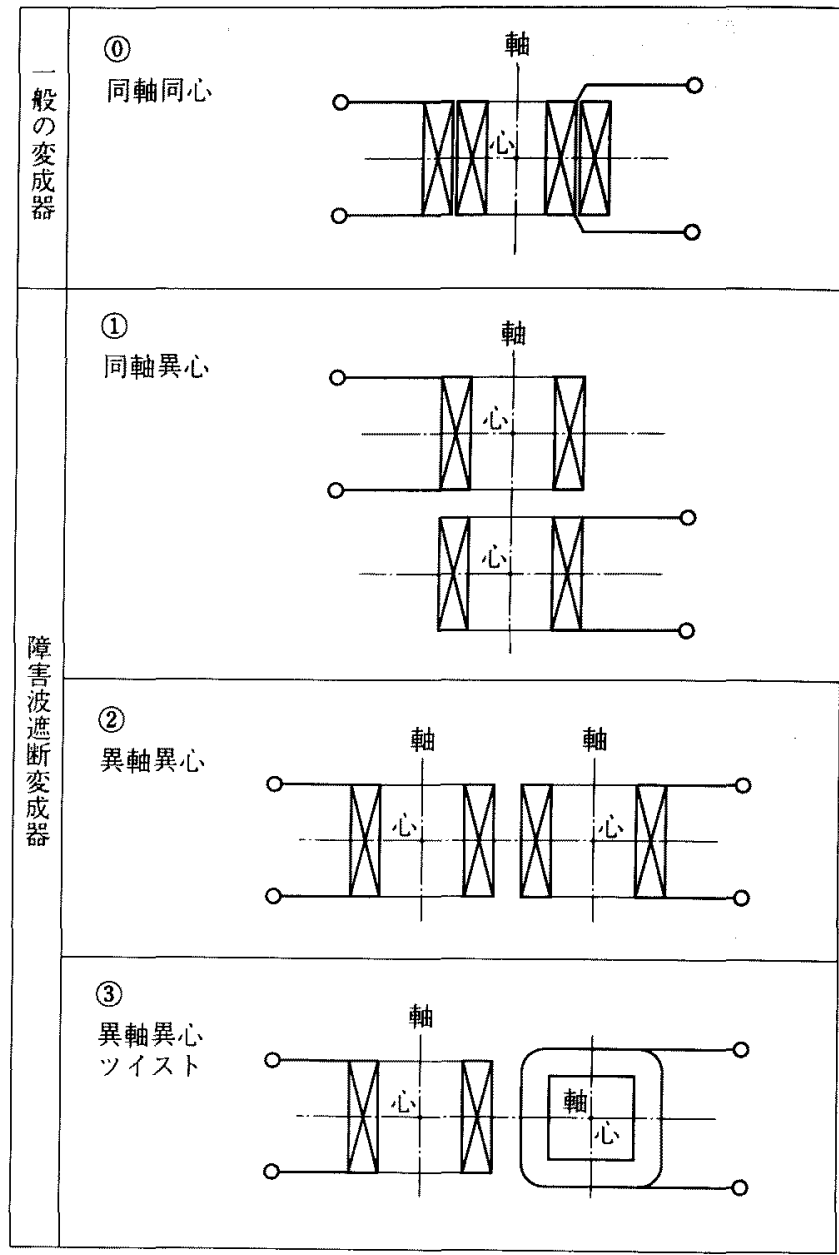

図5コイルの配置

Fig. 5. Coil arrangement

の変成器になぞらえて考えたとき，外形や材料利用率等も 考慮しないとならないので，取り得る配置は基本的に図 5 の(1)，(2)，(3)の三種類になる。(1)は同軸異心であり，(2)は 異軸異心であり，(3)は異軸異心で互いに軸線を直交させた 配置である。このうち(3は，もし一線一回巻のコイルであ れば，1次コイルから空中を通可磁束は2次コイルに鎖交せ ず平行するから2次側起電力は零となり，ノイズ防止上理 想の配置となる。しかし体積のある実際のコイルではわず かに斜めに鎖交して2次起電力が発生する部分が出てくる。

この基本的な三種類の実用になる形のものについて計算 することは容易でないので，以下の実験により比較検討し てみる。

5. 実験 $I=$ 空中にコイルのみを配置した場合とそ の結果

〈5・1〉測定サンプル＼cjkstart特に高いノイズ遮断効果を狙 つて設計すれば一見して変成器と思えないような形のもの にさえなるが，それでは汎用性を失うので，最も一般的な EIAJ-RC-2724 規格EI-66 ${ }^{(13)}$ の打抜き珪素鋼板のラミネー 


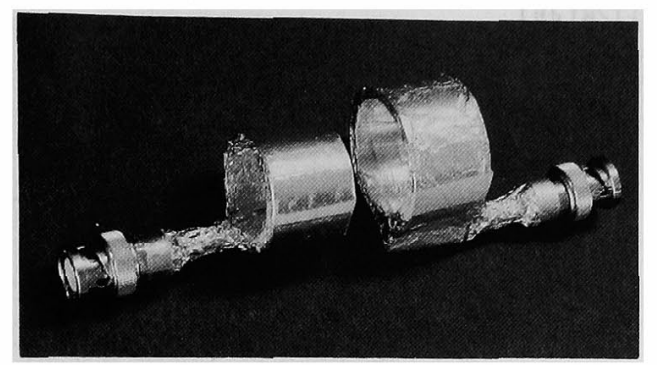

コイル径 外側 $30 \mathrm{~mm} \phi \quad$ 内側 $25 \mathrm{~mm} \phi$

コイル長 $20 \mathrm{~mm}$ 導体径 $2 \mathrm{~mm} \phi$

巻回数 3 回

アルミ箔 $20 \mu \mathrm{m}$ 同軸コード $3 \mathrm{D} 2 \mathrm{~V}$

図6 サンプル

Fig. 6. Sample

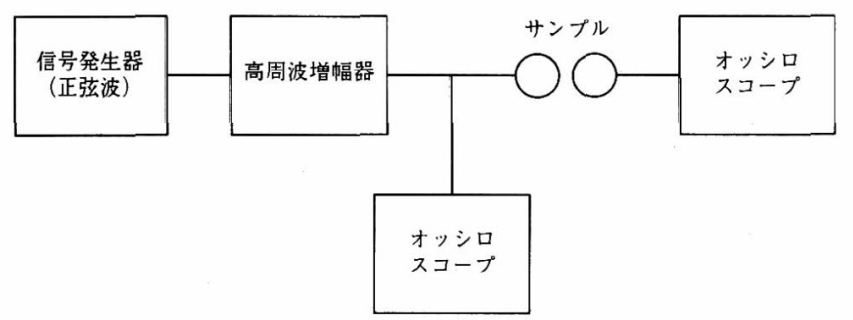

図7ノイズ測定ダイヤグラム

Fig. 7. Measurement diagram of noise

卜鉄心に当てはめて，その空寸法内に収まるサイズの外径 を採った図6のコイルで比較測定する。コイルは $20 \mu \mathrm{m}$ の アルミ箔で被覆して遮へいし ${ }^{(14)} 、$ 静電容量結合を除くと共 に外来輻射ノイズを排除する。

$\langle 5 \cdot 2\rangle$ 測定方法 今回は図7のように正弦波の信号発 生器と高周波堌幅器と互いにゲイン調整した同機種のオッ シロスコープ 2 台を用い, $2 \mathrm{~m} \times 2 \mathrm{~m}$ のアルミ製グランドプ レーン上に総ての器具・サンプルを配置して結線する ${ }^{(15)}$ 。 配線は総て遮へいし, 各電源線はアイソレートする。サン プルはグランドプレーンに近接した空中に，1次と 2 次のコ イルを互いに $5 \mathrm{~mm}$ 隔てて, 図5の(1)(1)(2)(3)の位置関係を 保つように絶縁物で保持し固定する。周波数をパラメータ にとって波形を観測しながら，一定間隔及びカーブの变化 点ごとに1次と 2 次のコイルの電圧の波高值を記録し， (3) 式より減衰率として算出し，表1にまとめる。

$$
\left.A=20 \log _{10} \frac{E_{2}}{E_{1}} 〔 \mathrm{~dB}\right)
$$

\section{$A$ は減衰率}

$$
\begin{aligned}
& E_{1} \text { は } 1 \text { 次コイルの電圧 } \\
& E_{2} \text { は } 2 \text { 次コイルの電圧 }
\end{aligned}
$$

〈5・3〉測定結果 まとめた表1の値より, 図6のサン
表 1 同軸同心配置とその他の配置の減衰率の違い

\begin{tabular}{|c|c|c|c|c|}
\hline \multirow{2}{*}{$\begin{array}{c}\text { 測定周波数 } \\
(\mathrm{Hz})\end{array}$} & \multicolumn{4}{|c|}{ 滅 衰 率 $(\mathrm{dB})$} \\
\hline & $\begin{array}{l}\text { 同軸同心 } \\
\text { (図5の@). }\end{array}$ & $\begin{array}{l}\text { 同軸異心 } \\
\text { \{図5の(1) }\end{array}$ & $\begin{array}{l}\text { 異軸異心 } \\
\text { (図5の(2)) }\end{array}$ & $\begin{array}{c}\text { 異軸異心ツイスト } \\
\text { (図5の(3)) }\end{array}$ \\
\hline $10 \mathrm{k}$ & -3.3 & -18.3 & -26.8 & -41.8 \\
\hline $25 \mathrm{k}$ & -2.7 & -17.7 & -26.3 & -41.9 \\
\hline $50 \mathrm{k}$ & -2.7 & -17.4 & -26.2 & -44.3 \\
\hline $75 \mathrm{k}$ & -2.8 & -17.2 & -26.3 & -45.0 \\
\hline $100 \mathrm{k}$ & -2.6 & -16.9 & -26.2 & -46.8 \\
\hline $250 \mathrm{k}$ & -2.8 & -16.1 & -26.2 & -51.2 \\
\hline $500 \mathrm{k}$ & -2.9 & -15.9 & -26.3 & -58.0 \\
\hline $750 \mathrm{k}$ & -2.9 & -15.6 & -26.2 & -62.3 \\
\hline $1 \mathrm{M}$ & -3.0 & -15.5 & -26.4 & -63.8 \\
\hline $2.5 \mathrm{M}$ & -3.0 & -15.4 & -26.1 & -67.1 \\
\hline $5 \mathrm{M}$ & -2.9 & -15.3 & -26.1 & -68.2 \\
\hline $7.5 \mathrm{M}$ & -3.0 & -15.4 & -26.1 & -67.8 \\
\hline $10 \mathrm{M}$ & -2.9 & -15.6 & -26.1 & -72.0 \\
\hline $25 \mathrm{M}$ & -3.0 & -15.3 & -26.2 & -74.1 \\
\hline $50 \mathrm{M}$ & -4.1 & -18.3 & -29.7 & -70.3 \\
\hline $75 \mathrm{M}$ & -4.4 & -22.1 & -34.0 & -61.8 \\
\hline $100 \mathrm{M}$ & -3.9 & -25.2 & -37.6 & -60.0 \\
\hline $125 \mathrm{M}$ & -3.5 & -25.3 & -38.3 & -53.8 \\
\hline $130 \mathrm{M}$ & -3.5 & -25.0 & -38.3 & -52.0 \\
\hline
\end{tabular}

Table 1. Difference of attenuation factor for coaxial concentric coil arrangement and other arrangements

プルの形状の空心コイルにおける配置の違いによる効果を 比較すると、図 5 の (1)の配置（同軸同心）に比べ，同(1)(2) (3) と順次に著しく磁束の鎖交が減じて行くことがわかる。

\section{6. 実験 II＝配置したコイルに磁心を加えた場合と その結果}

$\langle 6 ・ 1\rangle$ 測定サンプル 次に図5の(0)(1)(2)(3)のように それぞれ配置したコイルに磁心（鉄心）を組合わせて，変 成器として必要な構造を備えたサンプルではどうなるか測 定する。実験 I と比べ磁心が存在することと, コイルが基 本波の電圧に応じて多層多巻回数であることが異なる点で ある。各部については,

（1）コイルは〈5・1〉と同様の配虑から, 実験 I と同じ く EIAJ-RC-2724 規格EI-66 ${ }^{(13)}$ の打抜き珪素鋼板をラミネ

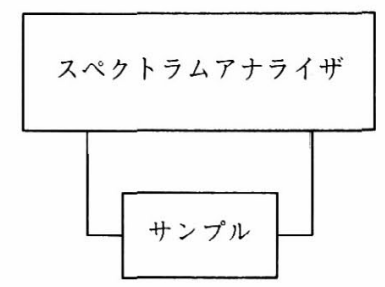

図8 ノイズスペクトル測定ダイヤグラム

Fig. 8. Measurement diagram of noise spectrum 


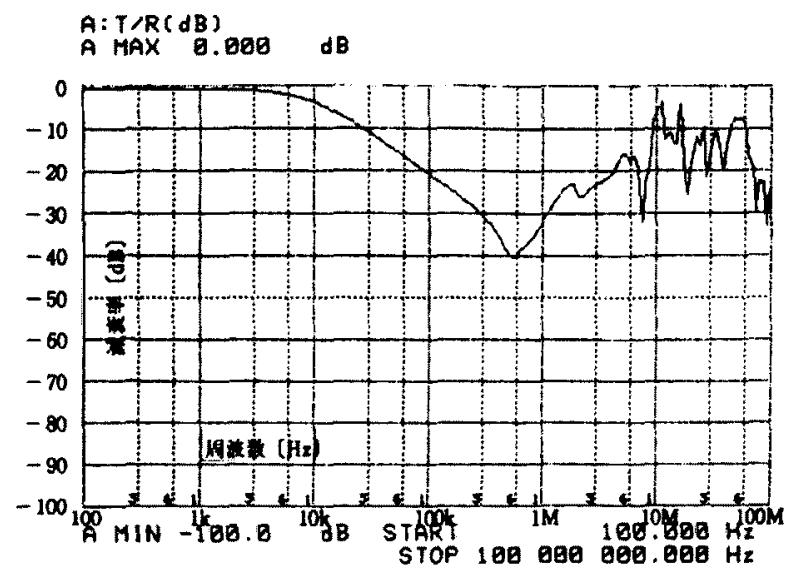

因 9 同軸同心配置（図 5(0)）のサンプルの減衰特性

Fig. 9. Noise attenuation characteristic of coaxial concentric arrangement（Fig. 5.(0) sample

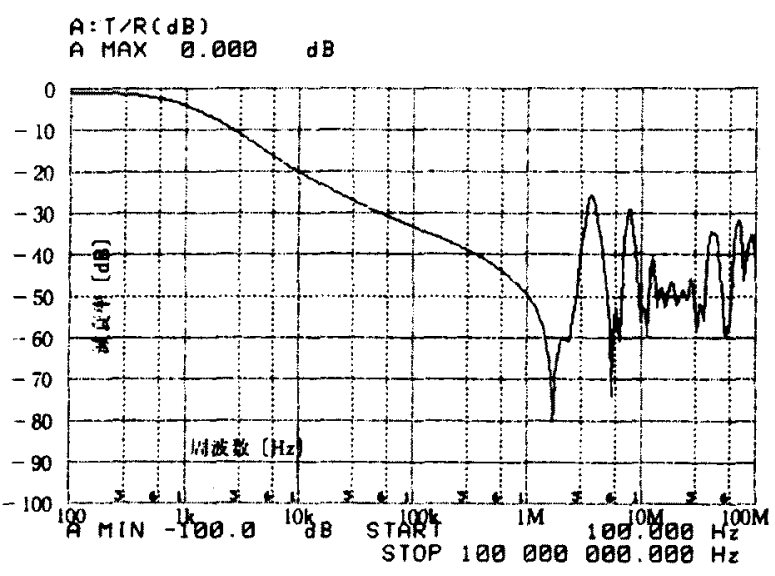

図 10 同軸異心配置 (図 5(1))のサンプルの減衰特性

Fig. 10. Noise attenuation characteristic of coaxial non concentric arrangement(Fig. 5.(1)) sample

一トした鉄心の空一杯に収まるサイズ（線径・巻回数は総 て同一) とする。配置は図5の(1)(1)(2)(3)に示した4種類と する。

（2）磁心は，図 5(0)(1)のものはEI-66のラミネート鉄心 そのもので同一寸法の外鉄形。(2)は脚の断面が(0)と同形 状の内鉄形。(3)は(2)の内鉄形の形状から，脚軸が互いに直 交するまでッイストした形 $(\langle 6 \cdot 4\rangle$ に記述し，以下ッイス ト形と記す)とする。

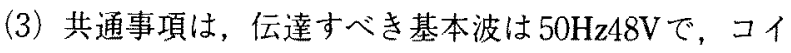
ルの線径 - 巻回数は総て同一, 巻数比は $1: 1$ とし, 各コ イルは $20 \mu \mathrm{m}$ 厚アルミ箔で覆い遮へいする。鉄心の材料は JIS-C 2552 50A470 級 $0.5 \mathrm{~mm}$ 厚の無方向性珪素鋼である。

〈6・2〉測定方法測定は今回は図8のようにスペクト ラムアナライザを用いることとし，その記録を図 9 ，図 10 , 図11，図 12 に表示する。

〈6・3〉測定結果＼cjkstart実験 I の結果の表 1 と比べて異なる 点として，低周波帯域の減衰率がより低く，高周波になる

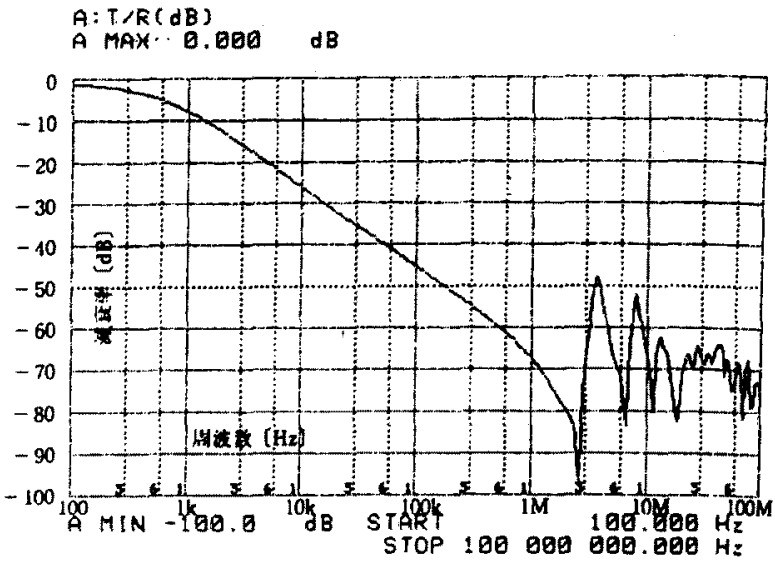

困 11 異軸異心配置 (図 5(2))のサンプルの減衰特性

Fig. 11. Noise attenuation characteristic of non coaxial non concentric arrangement (Fig. 5.(2)) sample
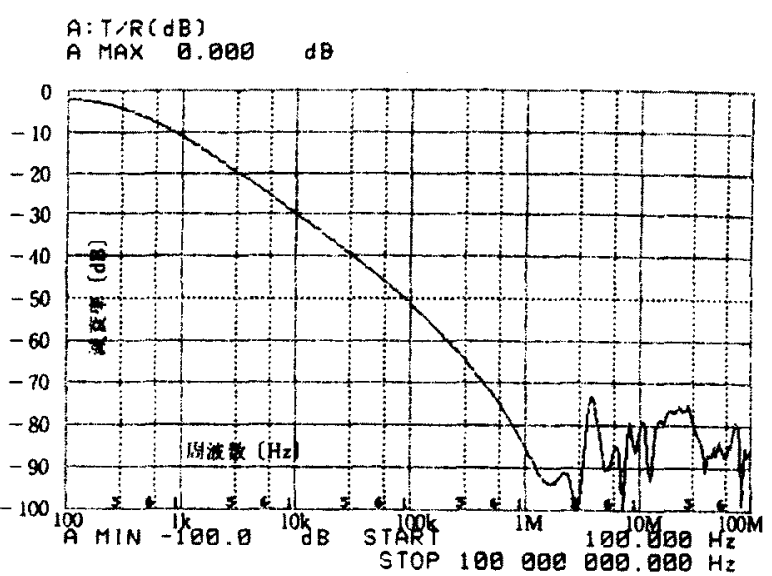

図12 異軸異心ツイスト配置（図5(3)）サンプルの減衰特性

Fig. 12. Noise attenuation characteristic of non coaxial non concentric and twist arrangement(Fig. 5.(3)) sample

に従って幾分か高くなっていることがある。この理由は磁 心（鉄心）の存在により，低周波帯域で磁束の鎖交がより 増加し, 高周波帯域では磁心内の損失で幾分か減少したこ とによる。

なお， $\mathrm{MHz}$ 帯に入ると共振現象が現われ，特性曲線がジ グザグになる。この理由はコイルが多層多巻回数であるこ とにより，コイル内の線間・層間の微細な分布静電容量と 漏れインダクタンスとの様々に複雑な組合わせのローカル の共振回路が存在し，それによる寄生振動が現われるため である。どのような電気部品・材料でも周波数の零から無 限大までのどこかで直列共振と並列共振を起こすことは， 避けられない問題ではあるが, 变成器の多巻回数コイルの ように極めて複雑な組み合わせになる部品では，このよう にランダムで複雑な様相を呈する。信頼性のさらなる向上 のためには，これを抑制することが技術的に高度に難かし いテーマとしてなお残るが，これについては稿を改めたい。 結果を各サンプルについて比較すると, 図5の(0)の配置 


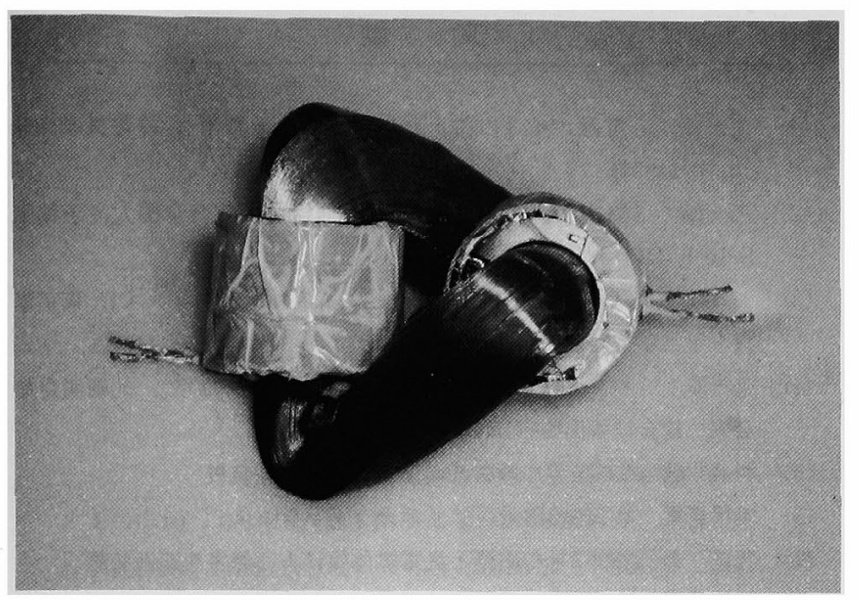

図 13 異軸異心ツイスト形の磁心とコイル

Fig. 13. Magnetic core and coil of non coaxial non concentric twisted shape

表2 ツイスト形と非ツイスト形の諸値の比較

Table 2. Comparison of core constants and characteristics of twisted transformer with untwisted transformer

\begin{tabular}{|c|c|c|c|c|c|}
\hline 分 & $\begin{array}{c}\text { 鉄心重量 } \\
\text { (g) }\end{array}$ & $\begin{array}{c}\text { 平均磁路長 } \\
(\mathrm{mm})\end{array}$ & $\begin{array}{c}\text { 無負荷損失 } \\
(\mathrm{W})\end{array}$ & 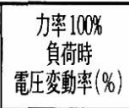 & 効 \\
\hline $\begin{array}{c}\text { (A) } \\
\text { ッイスト形 }\end{array}$ & 705 & 249 & 0.76 & 9.73 & 91.33 \\
\hline $\begin{array}{c}\text { (B) } \\
\text { 非ツイスト形 }\end{array}$ & 580 & 214 & 0.64 & 8.91 & 93.44 \\
\hline$\frac{\mathrm{A}}{\mathrm{B}}$ & 1.22 & 1.16 & 1.18 & 1.09 & 0.98 \\
\hline
\end{tabular}

に比べ，同(1)(2)(3)と順次に著しくノイズ減衰率が高くな ク, (0)に比べ(3)では周波数の高い領域で $10^{4}(80 \mathrm{~dB})$ 程の開 きが出ることがわかる。

また，図5の(10)，(1)，(2)，(3)の順に最初に現われる共振 点が周波数の高い方に（好ましい方向に）移行する。

〈6・4〉 ッィスト形磁心について 図5の(0)と(1)のもの の形状は一般の変成器の外鉄形と近似している。また同図 (2)のものの形状は一般の変成器の内鉄形と近似している。 しかし同図(3)の異軸・異心・ツイスト形のものはこれまで に見られず一般に無い形状であり，ノイズ防止の機能に徹 した障害波遮断変成器専用の形と言える。

これには幾つかの製作法（それによる細部の相違は生ず る)を試みてきた結果, 現時点で総合して最も良い結果を 生むことができたものの形状を図 13 に示す。同図中の脚軸 を直交するまでッイストした脚部（コイルの装着部分）の 断面は円形であり，継鉄部分の断面は棈円形である。この 部分を棈円形にすることにより磁路長が長くなるのを少し にとどめている。1回毎の周長と幅を加減して巻取った電 磁鋼帯を成形した後焼鈍処理してある。図は遮へいを総て
除いたコイルと鉄心だけを示している。

ッイストしたことにより磁路長が長くなり，また屈曲部 が増すことになる。それによって基本波磁束の空中への漏 えいが増して，基本波の伝達にどれ程の違いが生ずるかを 比較してみた結果を表 2 に示す。同表の（A）は図13のッ イスト形, 同（B）は,ッイストせず（コイルは図5(2)の配 置になる)，しない分だけ磁路が短い他は総て (A) と同じ ものであり，各 4 個づつを測定した平均值の比較である。

性能上の要点を考察すれば，図12に見るように，ツイス トしたことにより全域にわたって他より遥かにノイズ減衰 率が高く，ことに周波数の高い方で充分な值を保持するこ とができている。また表 2 に見るようにツイストしたこと による効率の低下を略 $2 \%$ に また力率 $100 \%$ 負荷におけ る電圧変動率の増加を略 $0.8 \%$ にとどめられたことが小さく ない成果である。

\section{7. 用途上の考察}

〈7・1〉 3種類のコイル配置を採った障害波遮断変成器の それぞれに，用途に即した考察を加えれば下記の通りである

（1）異軸異心ツイスト形（図 5 (3)の配置）は極めて高い 減衰率・信頼性を要求される場合に使用するのに適してい る。素材は一般変成器に比へて特に高価にはならないが, 加工度が高いことから他よりコスト高になることは避けら れず，この点に課題を残しているが，厳しい条件下におけ る切札となり得る最高性能形である。

(2) 異軸異心形（図 5, (2)の配置）は，中等度から高等度 の高い防止効果を得たい場合に適している。その理由はお およそー50dB〜ー60dB 以上の良好な減衰特性が得られ， ことに周波数の高い領域での効果が高いからである。効率 は一般変成器 (同軸同心形) に比べ $3 \%$ 程度の低下ですみ, 目的を考えれば許容できる範囲であろう。ただし電圧変動 率が数\%増加することを使用に当たり配虑した方がよい。

(3) すでに公害となっているノイズ障害の防止に役立て るにはできるだけ広く普及できる用品もなければならず, その視点からは同軸異心形（図5(1)の配置）が適している。 なぜならば基本の 3 種類のうちでは最も減衰率が低いとは 言いながら，ノイズ防止用品中でもかなり高いおおよそー $30 \mathrm{~dB} \sim-40 \mathrm{~dB}$ 以上の減衰率が得られ，また効率と電圧変 動率も一般変成器の同軸同心形に比べ $1 \%$ - $2 \%$ 程度の低 下で済む。更に流通量の多い安価な資材が使い易く量産に 適していて，コストが低くできるからである。

〈7・2〉 なお一般変成器に比べてコストが高くなる理由 はツイスト形を除けばコイルと磁心部分にはほとんど無く, 全体を良好な電磁遮へい構造にする必要があることと，そ れにより殊に恒久設備用の大型では絶縁耐電圧と冷却に難 しさが生ずることにある。

\section{8. まとめ}

ノイズ障害防止上重要性の増している電力回路用アイソ 
レート素子である障害波遮断変成器の，コイル配置に基づ いた各構造と特性について解析と実験を行った。要約する と下記のとおりになる。

（1）ノイズを伝達させない目的の障害波遮断変成器にお いては, 高周波実効透磁率の低い磁心により, 高周波のコ イル間相互誘導を防止する。しかしノイズの周波数が高く なる程その磁束は実効透磁率の低い磁心から離れ，コイル 内に必ず存在する空心及びコイル周辺に必ず存在する空間 や絶縁物中を通過し，相互誘導を生じてノイズを伝達し， 目的に反するようになる。

（2）従ってこの空心・空間や絶縁物中を通路とする高周 波磁束をどのように処理し, 相互誘導を防ぐかが, 最も重 要な課題となって残る。

（3）その解決には, 通常の変成器と反して，1次と 2 次の コイルを密接させず引き離して配置することが最も有効な 手段となるし，それによりノイズ防止素子全般の中でも優 れた特性を持つようになり，回路をアイソレートできる特 質を活かした，有力なノイズ防止素子となり得る。

（4）実用となり得るコイル配置には三種類の基本形が存 在する。そして，その中で最もノイズ遮断の効果の高い異 軸異心ツイスト形について最近の成果を示しながら, 三種 類の各々によりノイズ遮断と基本波の電力の伝達上の性能 とコストに差異が生ずること, 及びそれを用途に応じて使 い分けることによって，より広範で多様な需要に応えられ るようになることを示した。

(平成 9 年 1 月 22 日受付, 同 9 年 7 月 4 日再受付)

\section{文献}

（1）矢ヶ崎：「電磁ノイズの防止とアイソレート技術」, 静電気学会誌 18, 3 (1994)

（2）矢ヶ崎：「障害波遮断変圧器」，電子通信学会総合全国大会予稿集 S-16-6 (1978)

（3）矢ケ崎：「電子機器のノイズ对策とノイズカットトランス」, 東京電 機大学大学院特別講義 予稿 (1986)

（4）矢ヶ崎：「ハンドフックノイズ対策最新技術 V V 章 VIII章」，同編集委員 会編 総合技術出版 (1986)

（5）特許 第 1092320 号：障害波の磁路による遮断装置

（6）実用新案 第 1484042 号：ノイズカットトランス

（7）特許 第 1228957 号：磁路と良電導体板による障害波迸断装置

（8）実用新案 第1626234号：ノイズカットトランス

(9) 実用新案 第1626235号：ノイズカットトランス

(10) 特許第1714361号：ノイズ防止トランス

(11) Henry W.Ott : "Noise Reduction Techniques in Electronic Systems", Bell Telephone Laboratories In Corporated (1976)

（12）電気学会：電気工学ハンドブック 1978 年版 第 2 編電気物理

（13）（社）日本電子機械工業会：電子機器用トランスの鉄心積層板の寸法 (1994)

(14) Donald R. J. White : "Electromagnetic Shielding Materials and Performance", Don White Consultants, Inc", (1980)

(15) Hugh W.Denny : "Grounding for the Control of EMI", Don White Consultants, Inc (1983)

矢ヶ崎昭彦

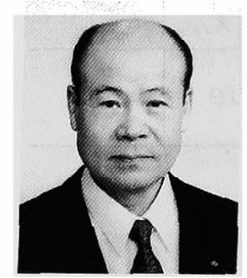

（正員）1928年 10 月 24 日生。1948年旧制長野工業 専門学校（現信州大学工学部）電気科卒業。1960 年株式会社電研精機研究所創立現在に至る, 代表取 締役。計測自動制御学会会貝。不要電波問题対策 協議会委員。 